\title{
Confronting Governance Challenges in the Nigerian \\ Universities within the Context of Failing Economy
}

\author{
Dare E. Arowolo (Corresponding Author) \\ Dept. of Political Science and Public Administration, Adekunle Ajasin University \\ Akungba Akoko, Ondo State, Nigeria \\ Tel: +2348035774375 E-mail: dreo2005@yahoo.com \\ Kolawole Ogunboyede \\ Dept. of Political Science and Public Administration, Adekunle Ajasin University \\ Akungba Akoko, Ondo State, Nigeria \\ Tel: +2347069052599 E-mail: kogunboyede@yahoo.com \\ Accepted: Feb 02, 2012 Published: March 03, 2013 \\ Doi:10.5296/ijld.v3i1.3038 URL: http://dx.doi.org/10.5296/ijld.v3i1.3038
}

\begin{abstract}
Human Capital Development is the fulcrum of development. It is therefore imperative that a lot of premium should be placed on capacity building. One of the institutions saddling with this onerous task is university. Universities are equipped with capacity and have human resource base to train individuals with a niche of specialisation. Such capacity however is deficient in Nigeria. The Nigerian universities are confronted with obstinate challenges crippling their capacity to deliver services. The paper identified the militating factors as having both endogenous and exogenous origin and insisted that the tottering economy of Nigeria contributed significantly to the capacity collapse and the falling standards of Nigerian Universities. It adopted content analysis as a method of data gathering and analysis. The main thrust of this paper is to examine these challenges with a view to proffering solution to adequately address them.
\end{abstract}

Keywords: Capacity, Development, Economy, Institutions, Services, Universities1.

\section{Introduction}

Universities are centres of excellence and research in all fields of human endeavours and development (Adewale, 2004; Kolawole, 2001). University, as an institution, is designed to provide an opportunity for policy formulation circuit, entrepreneurial skills and a catalyst for economic growth. All universities, regardless of ownership status, are faced with challenges of managing and running such institutions in a very competitive environment in which the university operates and in the operational context of unrepentantly failing economy. This is what is referred to as governance challenges, in that it has to do with managing, administering and running a university. The challenges become massive and obstinate as a result of the environment within which the universities must exist and coexist. The challenges are in two folds: the challenges of coping with the consequences of substantially weak economy; economy that is gradually failing and tottering with the attendant negative impacts that are enormous and potentially retrogressive, and the challenges of survival within the increasing competitiveness that characterises Nigerian universities, most especially between the old and new ones. 
The challenges are endogenous and exogenous. The exogenous factors, which are external in nature, are also in two subdivisions: the Nigerian immediate environmental factor, which includes the social, political and economic environments. The connotation of this stems from the understanding of how political economy of Nigeria operates which will inevitably give the understanding of the operational experience of new university in the context of such environment; and, the external factor which transcends Nigerian domestic territory arising from and occasioned by the unstoppable wave of globalisation, as no university in the world can pretend to be self-sufficient and can, therefore, exist as an island. There is persuasive need for interactions and exchange in different core areas between new universities and old universities in Nigeria on the one hand and the universities outside the shores of Nigeria that are older with massive opportunities on the other hand. This brings into fore the issue of inequality; inequality of age, opportunities, and infrastructure. The relationship, therefore, becomes asymmetrical and difficult to sustain with little or no opportunities in Nigeria.

The external challenges are as compelling as the internal ones. Some of the external challenges new universities must cope with include, but not limited to: insecurity, poverty, hunger, carbon emissions, economic meltdown, weak and peripheral nature of Nigerian economy, as well as managing complex, disparate interactions with universities abroad that have opportunities of technology and robust infrastructures (Fadile, 2006; Kolawole, 2000). The universities must react directly to all these challenges by designing appropriate and adequate curricular that can cope with and adapt to the challenges of the external environment in addition to engendering a bastion of academic culture that is sufficient enough to surmount these challenges.

The endogenous factors are the challenges that confront new universities internally such as infrastructural decay, illegal affiliation, instability of academic calendar, inadequate access, funding, lack of required critical knowledgeable individuals to drive development and over radicalisation of junior staff that are apathetical and perfidious, lack of strategic planning and strategic implementation, mounting of archaic programmes that can not cope in post modern society, direct interference by owners of university, challenge of beautification effort and the problem of adaptation to changes and innovation by staff and students, moral decadence and indecent lecturer-student relationship, decaying academic culture, extortion, problems associated with negotiated and over-bloated admission, quality of intake, among others.

The question most Nigerians are asking is whether more universities, rather than enhancing the capacity and functionality of existing private and public universities, would salvage the nation from the current doldrums in the tertiary education sector. This is more so in view of the fact that despite unprecedented increase in the number of private universities in the country and which have dwarfed the number of both federal and state universities, these private institutions can only contribute about 3.5 per cent to the total number of student enrolment (Ojerinde, 2010).

The 37 federal universities in the country contribute about 610,645 or $55.7 \%$ to student enrolment; the 37 state universities $-448,392$ or $40.9 \%$; while the 50 private universities contribute an abysmally paltry figure of 37,275 or $3.4 \%$. (NUC, 2012). The common reason for this low student enrolment ratio by the country's private universities is that, like most other private universities around the world, these private sector initiatives are usually elitist in nature. The tuition is far beyond the reach of the average Nigerian and ranges between N350, 000 and N1 million per semester. 
Secondly, many of the existing private universities in the country seem to have kicked off in a hurry and can only accommodate minimal number of students. Such institutions usually find it difficult to meet the conditions for the full accreditation of a substantial number of their courses .

The fact remains that proper funding and good management are the basic criteria for the healthy growth of universities anywhere in the world. It follows, therefore, that the level of funding and good management determines how successful a university is in terms of production of globally competitive products, stable academic calendar, research endowments and training and retraining of faculties and academics. Such proper funding and good management revolve around proper planning, visionary and focused leadership, high ethical standard and glaring sense of responsibility.

\subsection{Historical Development of University Education in Nigeria}

Understanding Nigerian universities necessitates the need to dig the historical background of the university education in Nigeria in order to appreciate the salient issues raised in this paper. The establishment of Elliot Commission in 1943 was a necessary impetus for the commencement of university education in Nigeria. This led to the founding of University College Ibadan (UCI) in 1948. UCI was an affiliate of the University of London (Ike, 1976). According to Ibukun (1997), the UCI was saddled with a number of problems at inception ranging from rigid constitutional provisions, poor staffing, and low enrolment to high dropout rate (Ajayi and Ekundayo, 2007).

In 1960, the Eastern Regional Government created University of Nigeria, Nsukka, the creation preceded the submission of the report of the Ashby Commission which was set up by the Federal Government in April, 1959 to among other things advise the Federal Government on the higher education needs of Nigeria. The implementation of that report actually led to the creation of University of Ife (Now Obafemi Awolowo University) in 1962 by the Western Region and Ahmadu Bello University in 1962 by the Northern Region and University of Lagos in 1962 by the Federal Government (Ajayi and Ekundayo, 2007). Babalola, Jayeoba and Okediran (2007) submitted that the University College, Ibadan became a full-fledged university in 1962, making both the UCI, Ibadan and University of Lagos the first two federal universities in Nigeria - the other three remained regional. The mid-western region also established University of Benin in 1970, making a total number of universities then in Nigeria six. The six universities established during this period 1960-1970 are still known as first generation universities (Ajayi and Ekundayo, 2007; Lawal, 2010).

The trio of Babalola, Jayeoba and Okediran (2007) affirmed that the the existing universities lacked requisite autonomy and were placed under close scrutiny and supervision of the Federal Government. According to Babalola, Jayeoba and Okediran (2007), the Federal Government did not strictly follow the contents of the existing National Development Plan (1975-1980) by establishing seven universities instead of the four already earmarked in the plan. It also took over the four regional universities in 1975. The seven newly created universities included: Calabar, Ilorin, Jos, Sokoto, Maiduguri, Port Harcourt and Kano. They are all referred to as second generation universities.

The third generation universities were established between 1980 and early 1990. They are: the Federal University of Technology in Owerri, Makurdi, Yola, Akure and Bauchi. While state universities were found in Imo, Ondo, Lagos, Akwa-Ibom, Oyo and Cross-Ricer states (Anyamelle, 2004; Ajayi and Ekundayo, 2007). 


\section{Macrothink Institute}

Universities established from 1991 till date are known as fourth generation universities. They comprise more of private universities, a number of state universities and Nigerian Open Universities (NOUN).

Table 1. List of Federal Universities

\begin{tabular}{|c|c|c|c|c|}
\hline $\mathbf{S} / \mathbf{N}$ & FEDERAL UNIVERSITIES & GENERATION & VICE CHANCELLOR & $\begin{array}{l}\text { YEAR } \\
\text { FOUNDED }\end{array}$ \\
\hline 1. & $\begin{array}{l}\text { Abubakar Tafawa Balewa University, } \\
\text { Bauchi }\end{array}$ & Third & $\begin{array}{l}\text { Professor Muhammad Hamisu } \\
\text { Mohammed }\end{array}$ & 1988 \\
\hline 2. & Ahmadu Bello University, Zaria & First & Professor Abdullahi M & 1962 \\
\hline 3. & Bayero University, Kano & Second & Professor Abubakar Adamu & 1975 \\
\hline 4. & $\begin{array}{l}\text { Federal University of Petroleum } \\
\text { Resources, Effurun }\end{array}$ & Fourth & Professor Babatunde Alabi & 2007 \\
\hline 5. & $\begin{array}{l}\text { Federal University of Technology, } \\
\text { Akure }\end{array}$ & Third & $\begin{array}{l}\text { Professor Adebiyi } \text { George } \\
\text { Daramola }\end{array}$ & 1981 \\
\hline 6. & $\begin{array}{l}\text { Federal University of Technology, } \\
\text { Minna }\end{array}$ & Third & $\begin{array}{l}\text { Professor muhammed } \mathrm{S} . \\
\text { Audu }\end{array}$ & 1982 \\
\hline 7. & $\begin{array}{l}\text { Federal University of Technology, } \\
\text { Owerri }\end{array}$ & Third & $\begin{array}{lll}\text { Professor } & \text { Chigozie } & \text { C. } \\
\text { Asiabaka }\end{array}$ & 1980 \\
\hline 8. & $\begin{array}{l}\text { Federal University, Dutse, Jigawa } \\
\text { State }\end{array}$ & Fourth & Professor Jubril Dahiru Amin & 2011 \\
\hline 9. & $\begin{array}{l}\text { Federal University, Dutsin-Ma, } \\
\text { Katsina }\end{array}$ & Fourth & Professor James O.I. Ayatse & 2011 \\
\hline 10. & $\begin{array}{l}\text { Federal University, Kashere, Gombe } \\
\text { State }\end{array}$ & Fourth & $\begin{array}{l}\text { Professor Mohammed Kabiru } \\
\text { Farouk }\end{array}$ & 2011 \\
\hline 11. & $\begin{array}{l}\text { Federal University, Lafia, Nasarawa } \\
\text { State }\end{array}$ & Fourth & $\begin{array}{l}\text { Professor (Mrs) Ekanem Ikpi } \\
\text { Braide }\end{array}$ & 2011 \\
\hline 12. & Federal University, Lokoja, Kogi State & Fourth & $\begin{array}{l}\text { Professor } \quad \text { Abdulmumini } \\
\text { Rafindadi }\end{array}$ & 2011 \\
\hline 13. & $\begin{array}{l}\text { Federal University, Ndufu-Alike, } \\
\text { Ebonyi State }\end{array}$ & Fourth & Professor Oye Ibidapo-Obe & 2011 \\
\hline 14. & $\begin{array}{l}\text { Federal University, Otuoke, Bayelsa } \\
\text { State }\end{array}$ & Fourth & Professor Mobolaji Aluko & 2011 \\
\hline 15. & Federal University, Oye-Ekiti & Fourth & Professor Chinedu O. Nebo & 2011 \\
\hline 16. & Federal University, Wukari, Taraba & Fourth & Professor Geoffrey Okogbaa & 2011 \\
\hline 17. & $\begin{array}{l}\text { Michael Okpara University of } \\
\text { Agriculture, Umudike }\end{array}$ & Third & Professor Hillary Odo Edoga & 1992 \\
\hline 18. & $\begin{array}{l}\text { Modibbo Adama University of } \\
\text { Technology, Yola }\end{array}$ & Third & Professor B.H. Usman & 1988 \\
\hline 19. & $\begin{array}{l}\text { National Open University of Nigeria, } \\
\text { Lagos }\end{array}$ & Fourth & Professor Vincent A. Tenebe & 2002 \\
\hline 20. & Nigerian Defence Academy, Kaduna & Third & Professor Aliyu Abdullahi & 1985 \\
\hline 21. & Nnamdi Azikiwe University, Awka & Third & Professor Boniface O. Egboka & 1992 \\
\hline 22. & Obafemi Awolowo University, Ile-Ife & First & Professor Bamitale Omole & 1962 \\
\hline 23. & Police Academy Wudil & Fourth & Professor Munzali Jibril & 2012 \\
\hline 24. & University of Abuja & Third & Professor J.S.A. Adelabu & 1988 \\
\hline 25. & University of Agriculture, Abeokuta & Third & Professor O.B. Oyewole & 1988 \\
\hline 26. & University of Agriculture, Makurdi & Third & Professor D.V. Uza & 1988 \\
\hline 27. & University of Benin & First & Professor Osayuki G. Oshodin & 1970 \\
\hline 28. & University of Calabar & Second & Professor James Epoke & 1975 \\
\hline 29. & University of Ibadan & First & Professor Isaac Folorunso A. & 1948 \\
\hline
\end{tabular}




\section{MlMacrothink}

International Journal of Learning \& Development

ISSN 2164-4063

2013, Vol. 3, No. 1

\begin{tabular}{|r|l|l|l|l|}
\hline 30. & University of Ilorin & Second & Professor Is'haq Oloyede & 1975 \\
\hline 31. & University of Jos & Second & $\begin{array}{l}\text { Professor Hayward B. } \\
\text { Mafuyai }\end{array}$ & 1975 \\
\hline 32. & University of Lagos & First & Professor Rahman Ade Bello & 1962 \\
\hline 33. & University of Maiduguri & Second & Professor M.M. Daura & 1975 \\
\hline 34. & University of Nigeria, Nsukka & First & $\begin{array}{l}\text { Professor Bartholomew N. } \\
\text { Okolo }\end{array}$ & 1960 \\
\hline 35. & University of Port-Harcourt & Second & Professor Joseph Ajienka & 1975 \\
\hline 36. & University of Uyo & Third & Professor Comfort M. Ekpo & 1991 \\
\hline 37. & Usman Danfodiyo University & Second & Professor Riskuwa A. Shehu & 1975 \\
\hline
\end{tabular}

Source: NUC, 2012.

Table 2. List of State Universities

\begin{tabular}{|c|c|c|c|}
\hline $\mathbf{S} / \mathbf{N}$ & STATE UNIVERSITIES & VICE CHANCELLOR & YEAR FOUNDED \\
\hline 1. & Abia State University, Uturu Abia & Prof. Chibuzo B. Ogbuagu & 1980 \\
\hline 2. & Adamawa State University, Mubi Adamawa & Prof. Alkasum Abba & 2002 \\
\hline 3. & $\begin{array}{lll}\text { Adekunle } & \text { Ajasin } & \text { University, } \\
\text { Akungba-Akoko, Ondo State } & \end{array}$ & Prof. Nahzeem O. Mimiko & 1999 \\
\hline 4. & $\begin{array}{l}\text { Akwa Ibom University of Technology, Uyo } \\
\text { Akwa Ibom }\end{array}$ & $\begin{array}{l}\text { Prof. Sunday W. Petters } \\
\text { (Ag.) }\end{array}$ & 2004 \\
\hline 5. & Ambrose Alli University, Ekpoma Edo & Prof. Sam O. Uniamgboko & 1980 \\
\hline 6. & $\begin{array}{l}\text { Anambra State University of Science and } \\
\text { Technology, Uli Anambra }\end{array}$ & Prof. C.C. Anene (Ag.) & 2004 \\
\hline 7. & Bauchi State University, Gadau & $\begin{array}{l}\text { Prof. Ezzildin, } \\
\text { Abdulrahman }\end{array}$ & 2011 \\
\hline 8. & Benue State University, Makurdi & Prof. Charity A. Angya & 1992 \\
\hline 9. & Buka Abba Ibrahim University, Damaturu & Prof. Musa Alabe & 2006 \\
\hline 10. & $\begin{array}{l}\text { Cross River State University of Science and } \\
\text { Technology Cross River }\end{array}$ & Prof. Effiom Ini-Obong & 2004 \\
\hline 11. & Delta State University, Abraka & Prof. E.A. Arubaye & 1992 \\
\hline 12. & Ebonyi State University, Abakaliki & Prof. F.I. Idike & 2000 \\
\hline 13. & Ekiti State University, Ado-Ekiti & Prof. E.D. Adelowo (Ag.) & 1988 \\
\hline 14. & $\begin{array}{l}\text { Enugu State University of Technology, } \\
\text { Enugu }\end{array}$ & Prof. Cyprian C. Onyeji & 1981 \\
\hline 15. & Gombe State University, Gombe & Prof. Abdullahi Mahadi & 2004 \\
\hline 16. & $\begin{array}{l}\text { Ibrahim Badamosi Babangida University, } \\
\text { Lapai }\end{array}$ & Prof. Ibrahim Kolo & 2005 \\
\hline 17. & $\begin{array}{l}\text { Ignatius Ajuru University of Education, } \\
\text { Rumuoumeni }\end{array}$ & $\begin{array}{l}\text { Prof. R.D. Green-Osahogulu } \\
\text { (Ag.) }\end{array}$ & 2010 \\
\hline 18. & Imo State University, Owerri & Prof. B.E.B Nwoke. & 1992 \\
\hline 19. & Kaduna State University Kaduna & $\begin{array}{lll}\text { Prof. } & \text { William } & \text { Barnabas } \\
\text { Qurix } & & \\
\end{array}$ & 2004 \\
\hline 20. & $\begin{array}{l}\text { Kano University of Science \& Technology, } \\
\text { Wudil-Kano }\end{array}$ & Prof. Ibrahim Garba & 2000 \\
\hline 21. & Kebbi State University, Kebbi & Dr. Amina Abubakar & 2006 \\
\hline 22. & Kogi State University, Anyigba Kogi & Prof. Hassan S. Isah & 1999 \\
\hline 23. & Kwara State University, Ilorin & Prof. A. Na-Allah & 2009 \\
\hline 24. & $\begin{array}{l}\text { Ladoke Akintola University of Technology, } \\
\text { Ogbomoso }\end{array}$ & Prof. Adeniyi Suliman & 1990 \\
\hline
\end{tabular}




\section{Macrothink}

International Journal of Learning \& Development

ISSN 2164-4063

2013, Vol. 3, No. 1

\begin{tabular}{|r|l|l|l|}
\hline 25. & Lagos State University, Ojo Lagos & Prof. John O. Obafunwa & 1983 \\
\hline 26. & Nasarawa State University, Keffi & Prof. S.O.O. Amali & 2002 \\
\hline 27. & Niger Delta University, Yenagoa & Prof. Chris Ikporukpo (Ag.) & 2000 \\
\hline 28. & Northwest University, Kano & - & 2012 \\
\hline 29. & Olabisi Onabanjo University, Ago-Iwoye & Prof. Adewale A Olaitan & 1982 \\
\hline 30. & $\begin{array}{l}\text { Ondo State University of Science \& } \\
\text { Technology, Okitipupa }\end{array}$ & Prof. Tolu Odugbemi & 2008 \\
\hline 31. & Osun State University, Oshogbo & Prof. Sola Akinrinade & 2006 \\
\hline 32. & Plateau State University, Bokkos & Prof. N. Gomwalk & 2005 \\
\hline 33. & $\begin{array}{l}\text { Rivers State University of Science and } \\
\text { Technology, Port Harcourt }\end{array}$ & Prof. Barineme Beke Fakae & 1979 \\
\hline 34. & Sokoto State University, Sokoto & - & 2009 \\
\hline 35. & $\begin{array}{l}\text { Tai Solarin University of Education, } \\
\text { Ijebu-Ode }\end{array}$ & Prof. Segun Awonusi & 2005 \\
\hline 36. & Taraba State University, Jalingo & Prof. Ahmed Usman Jalingo & 2008 \\
\hline 37. & Umaru Musa Yar'Adua University, Katsina & Prof. Mu'uta Ibrahim & 2006 \\
\hline
\end{tabular}

Source: NUC, 2012

Table 3. List of Private Universities

\begin{tabular}{|c|c|c|c|}
\hline $\mathbf{S} / \mathbf{N}$ & PRIVATE UNIVERSITIES & VICE CHANCELLOR & $\begin{array}{l}\text { YEAR } \\
\text { FOUNDED }\end{array}$ \\
\hline 1. & Achievers University, Owo & Prof. J.A. Odebiyi & 2007 \\
\hline 2. & Adeleke University, Ede & - & 2011 \\
\hline 3. & Afe Babalola University, Ado Ekiti & Prof. (Mrs) Sidi Oho & 2009 \\
\hline 4. & $\begin{array}{l}\text { African University of Science \& Technology, } \\
\text { Abuja }\end{array}$ & Prof. Charles Chidume (Ag.) & 2007 \\
\hline 5. & Ajayi Crowther University, Ibadan & Prof. Adekunle Adeniran (Ag.) & 2005 \\
\hline 6. & Al-Hikmah University, Ilorin & Prof. S.A. Abdulkareem & 2005 \\
\hline 7. & American University of Nigeria, Yola & Prof. Dr. Margee Ensign & 2003 \\
\hline 8. & Babcock University, Illishan-Remo & Prof. Kayode J. Makinde & 1999 \\
\hline 9. & Baze University & Prof. Michael Hodd & 2011 \\
\hline 10. & Bells University of Technology, Otta & Prof. A.I. Adeyemi & 2005 \\
\hline 11. & Benson Idahosa University, Benin City & Prof. Gideon E.D. Omuta & 2002 \\
\hline 12. & Bingham University, New Karu Nasarawa & Prof. F.I. Anjorin (Ag.) & 2005 \\
\hline 13. & Bowen University, Iwo Osun & Prof. T. Olagbemiro & 2001 \\
\hline 14. & Caleb University Lagos & Prof. Ayodeji O. Olukoju & 2007 \\
\hline 15. & Caritas University, Enugu Enugu & Prof. L.C. Onukwube & 2005 \\
\hline 16. & CETEP City University, Mowe Ogun & Prof. Akin Aju & 2005 \\
\hline 17. & Covenant University, Ota Ogun & Prof. Aize O. Obayan & 2002 \\
\hline 18. & Crawford University, Igbesa Ogun & Prof. M.I. Ige & 2005 \\
\hline 19. & Crescent University, Abeokuta Ogun & Prof. Sherifdeen A. Tella & 2005 \\
\hline 20. & Elizade University, Ilara Mokin & - & \\
\hline 21. & Evangel University, Akaeze & - & \\
\hline 22. & Fountain University, Osogbo & Prof. H.O.B. Oloyede & 2007 \\
\hline 23. & $\begin{array}{l}\text { Godfrey } \quad \text { Okoye } \\
\text { Ugwuomu-Nike-Enugu }\end{array}$ & Prof. C. Anieke & 2009 \\
\hline 24. & Gregory University, Uturu & - & \\
\hline 25. & Igbinedion University, Okada Edo & Prof. Eghosa E. Osaghae & 1999 \\
\hline 26. & Joseph Ayo Babalola University, Ikeji-Arakeji & Prof. Sola Fajana & 2006 \\
\hline
\end{tabular}




\section{MIMacrothink}

International Journal of Learning \& Development

ISSN 2164-4063

2013, Vol. 3, No. 1

\begin{tabular}{|r|l|l|l|}
\hline 27. & Katsina University, Katsina & Dr. S. Ibrahim & 2005 \\
\hline 28. & Landmark University, Omu-Aran & Prof. Mattew Ola-Rotimi Ajayi & 2011 \\
\hline 29. & Lead City University, Ibadan & Prof. J.B. Aladekomo & 2005 \\
\hline 30. & Madonna University, Okija, Anambra State & Prof. P.I. Akubue & 1999 \\
\hline 31. & Mcpherson University, Seriki Sotayo, Ajebo & - & \\
\hline 32. & Nigerian-Turkish Nile University, Abuja & Prof. D. Kaptanogu & 2009 \\
\hline 33. & Novena University, Ogume Delta State & Prof. J.M.O. Eze (Ag.) & 2005 \\
\hline 34. & Obong University, Obong Ntak & Prof. Enefiok S. Udo & 2007 \\
\hline 35. & Oduduwa University, Ipetumodu & Prof. J. Adeleke Ogunwale & 2009 \\
\hline 36. & Pan-African University, Lagos & Prof. Juan Manuel Elegido & 2002 \\
\hline 37. & Paul University, Awka-Anambra State & Prof. G. Igboeli & 2009 \\
\hline 38. & Redeemer's University, Mowe & Prof. I.O.O. Komolafe (Ag.) & 2005 \\
\hline 39. & Renaissance University, Enugu & Prof. Obiora S. Ejim & 2005 \\
\hline 40. & Rhema University, Obeama-Asa-Rivers State & Prof. O.C. Onwudike & 2009 \\
\hline 41. & Salem University, Lokoja & Prof. Paul Omaji & 2007 \\
\hline 42. & Samuel Adegboyega University, Ogwa & - & 2011 \\
\hline 43. & Southwestern University, Oku-Owa & - & 2012 \\
\hline 44. & Tansian University, Umunya & Prof. Nduka Uraih & 2007 \\
\hline 45. & University of Mkar, Mkar & Prof. Emmanuel Hemen Agba & 2005 \\
\hline 46. & Veritas University & 2007 \\
\hline 47. & Wellspring University, Evbuobanosa, Edo State & Prof. David Ker & 2009 \\
\hline 48. & Wesley University of Science \& Technology,, Prof. Tade Badejo & 2007 \\
\hline 49. & Wndo & & \\
\hline 50. & Wukari Jubilee University, Wukari Taraba & Prof. G.G. Hugbo & 2007 \\
\hline
\end{tabular}

Source: NUC, 2012

\section{Challenges of Universities and the Concept of Competition}

The compelling need for the Nigerian universities to interact with other universities outside the shores of Nigeria pose serious challenges as the former lack requisite infrastructural facilities to adequately compete with other universities. The challenges are multifarious and complex. It is a combination of limited access, increasing cost, decreasing quality, and inflexibility in course selection. Others are struggling economies and obsolete organizational structures facing university education in Nigeria today.

Perhaps, the most formidable task confronting university education in Nigeria is to articulate the triple relationship between the mission of the university; the specific needs of university's political, social, economic, and cultural environment; and, the adaptation of the universities to the challenges of modernity. One of the challenges of Nigerian universities is inadequacy of qualified and skilled academic staff. There is decreasing rate of job seekers with $\mathrm{PhD}$, few of the potential academics with $\mathrm{PhD}$ prefer to take up appointment with universities abroad with better facilities and environment conducive for research and learning. Infrastructures is another factor militating against Nigerian universities. Many of the Nigerian universities are populated by dilapidated infrastructures. Many of the courses in Nigerian universities are archaic.

There are challenges of mounting modern programmes as there is inadequacy of competent lecturers and very weak or decaying infrastructural base. There is a challenge of entrenching academic culture. Academic culture, perceived as an arrangement, a commitment to the system that is driven by intellectualism, excellence and facts, devoid of subjectivity and other 
considerations outside competence and merit, is a sine qua non to the actualisation of the vision of university. It is a commitment to sustenance of tradition and absolute respect for norms. Nigerian universities should prevent or stamp-out culture of sale of handouts, circuit of negotiated and over-bloated admission, plagiarism and over radicalisation of junior staff that is not receptive to training.

Quality of intakes is generally low in Nigeria. The issue of brain drain is also very retrogressive. Over the past decades, as a result of a gradual exodus of many Nigerian talented faculty and research-inclined academics, Nigeria universities have faced continuous search for innovative and young academics. Some faculty abandoned academia for other sectors of the economy, where professionals and scientists receive higher salaries and greater social recognition.

Funding is also a big challenge to Nigerian universities. Financial restrictions also create problems that impair quality research, causing friction between the universities and the owners, thus threatening the stability of institutions. The problems are more visible in the areas of faculty salaries, libraries, equipments, research and general funding of our universities today. Universities are ill-equipped and lecturers are poorly trained. Standard is falling in Nigerian universities. Over 70 percent of the laboratory equipment and library books in today's Nigerian universities, for example, were bought and placed between 1970s and 1980s. The majority of universities have misplaced their goals and allowed social, political and economic factors of their environment to create crises in their academic community. There are allegations of politically motivated decision-making, mutual back scratching, patronage and partisanship that have permeated our universities (Mimiko, 2010; Ojerinde, 2010; Lawal, 2010).

All these are challenges which are surmountable. What defines successful university is the ability to confront challenges and overcome them. It is, therefore, imperative for universities to see all these as challenges and not problems and to saddle themselves with strategies to confront and overwhelm these surmountable challenges.

There is therefore the need for Nigerian universities to change from being conventional producers of over-reliant, dependent graduates to becoming engines of community development. Many Nigerian University workers (both academic and non academic staff) have, ultimately, become impervious to change and innovation. Nigeria needs a new generation of universities that can serve as engines of both community development and social renewal with evidence of excellence and best practices that promote core competence in undergraduate programmes with a niche in entrepreneurial skills and initiatives.

\section{Conclusion and Recommendations}

The nature of society inherited from the British imperialists made it so difficult, if not impossible, for anything to work in Nigeria. Colonialism altered, deterred and retarded, to some extent, the existing traditional society and their pace of development. A Nigeria that was bequeathed was one that lacked adequate capital, markets and the appropriate technology to industrialise and favourably compete in the international world capitalist market. Nigeria is an enigma, a structure designed to fail, the British deliberately put up a geographical entity that would not work with attendant teething problems that are impermeable to development.

It is in this kind of society and environment that universities must operate and survive. A country with failing economy, economy that can not produce and provide running and portable water, a world of epileptic supply of electricity, economy that is surly to education 
and innovation, economy that does not revolve around human development. It is a double spending on any university operating in Nigeria as basic infrastructures through which university can thrive and grow are lacking and deteriorating. Granted the complex challenges facing Nigerian universities, it becomes appropriate to put forth the following measures to address and arrest this ugly trend:

- Government should strengthen its existing regulatory agencies like National Universities Commission (NUC) and Federal Ministry of Education to ensure that sanity is restored and maintained in the university campuses. This will prevent the trend of exploitation of students and parents and commercialisation of education and certificates. A strong, efficient and incorruptible monitoring system should be developed to ensure prompt realization of the objectives of Nigerian universities.

- It becomes enormous challenges for the universities to create pockets of functional system with stability in water supply, electricity, accommodation for both staff and students and general conducive environment. For Nigerian universities to cope and compete favourably on the global plane, it must define and design a domestic, home-grown arrangement that is micro but sufficient enough to guarantee security of both staff and students, provide platform for research and generate a sustainable academic culture.

- Fundamental reforms will be needed in the curriculum design, teaching and management of Nigerian universities. The universities need to help solve or contribute maximally to the efforts at solving the socio-economic and political challenges that face the nation. They should play a role in promoting infrastructure development. Pragmatic efforts should be deliberately coordinated in order to bring services of university to the reach of the people. This will require a qualitative change in the goals, vision, functions and structure of Nigerian universities.

- It is important to understand that the most critical challenge facing most universities will be to develop the capacity for change. Nigerian universities should seek to remove the constraints that prevent them from responding to the needs of a rapidly changing society. This can only be achieved by introducing democratic university structures and management styles that promote inclusiveness and collective deliberation in decision making arrangement. Decision making should be democratised and transparent as this will serve as propellant of development, impetus to scholarship and stimulant to academic culture.

- Universities should create and define ideal student-lecturer relationship supportive of the university's vision. Lecturers should come to terms with the sanctity and enormity of their job and should guide same jealously without subjecting it to undue negotiation, ridicule and reproach. Universities are inundated daily with experiences of 'naked' intervention from owners of the universities who, in many cases, personalise the official procedure of their universities and subject them to public relations outfit.

- On the whole, leadership becomes critical, both in terms of will and ability to mobilise resources for the attainment of university objectives. It is important, therefore, to adopt the leadership and management styles that inspire confidence in all who will be involved in the restructuring of university development. Restructuring also involves restructuring of interests which are invariably conflicting and have to be balanced. The essence of this, however, is that leadership role is crucial in the overall development of any university. 


\section{References}

Adewale A. (2004). NUC Reforms will Improve Standard. A Paper Delivered at the Conference Organized by NUC, Abuja, May.

Ajayi, I. A. and Ekundayo, H. T. (2007). "Funding Initiatives in University Education in Nigeria". In J. B. Babalola; G. O. Akpa; A. O. Ayeni ands. O. Adedeji (eds) Access,

Equity and Quantity in Higher Education. NAEAP Publications. Lagos: Awemark Printers.

Anyambele, S. C. (2004). Institutional Management in Higher Education; A Study of Leadership Approaches to Quality Improvement in University Management. Nigerian and Finish Cases. An unpublished Ph.D. Thesis submitted to the Department of Education, University of Helsinki.

Babalola, J. B.; Jaiyeoba, A. O. and Okediran, A. (2007). "University Autonomy and Financial Reforms in Nigeria: Historical Background, Issues and Recommendations

from Experience". In J. B. Babalola and B. O. Emunemu (eds.). Issues in Higher Education: Research Evidence from Sub-Saharan Africa. $\quad$ Lagos: Bolabay Publications.

Ibukun, W. O. (1997). Educational Management: Theory and Practice. Ado-Ekiti: Green Line Publishers.

Fadile S. (2006). Nigerian Education Sector. A paper delivered at the conference on Educational Development organized by the Federal Ministry of Education, Abuja.

Kolawole A. (2000) "Privatization and Public Morality: Professional Education Ethics and the Privatization of Tertiary Education in Nigeria" in Yann and Ogunsanya M.

(eds) The Dilemma of Post-Colonial Universities. IFRA/ABB. Ibadan: Intec Printers Ltd.

Ike, V. C.(1976). University Development in Africa: The Nigerian Experience. Ibadan: Oxford University Press.

Kolawole, D. (2001). "Labour Unions and Management of Industrial Disputes in the University System" in Omotoso, F. ed. Contemporary Issues in Public Administration. Lagos: Bolabay Publications. P. 14-20

Lawal, T. (2010). "Higher Education Policy in Nigeria: A Focus on Private Universities" in A.A. Agagu, Arowolo, D, L.A. Afinotan and Lawal, T. (eds) Public Administration in Nigeria. Akure: Alabi-Eyo \& Co. Ltd. Pp. 274-280

Mimiko, N.O. (2010). Beyond Guantanamo Bay: The Academia and Governance in Nigeria: Interrogating the Place of Alumni Associations in the Development of Higher Education. Keynote Address Delivered at the University of Ado-Ekiti, Alumni Association Homecoming Conference. Ado-Ekiti: Conference Hall, UNAD, December 10.

National University Commission (2012). List of Nigerian Universities and Years Founded. http://www.nuc.edu.ng/pages/universities.asp. Date Visited: 8/5/2012.

Ojerinde, D. (2010). Nurturing the Youth for Leadership through Tertiary Education in Nigeria; A Case Study of Adekunle Ajasin University, Akungba-Akoko. A Paper Presented at the Public Lecture Series. Akungba-Akoko: Adekunle Ajasin University, August, 9. 